\title{
Volatile Organic Constituents of Two Fractions of Leaves of Ficus vogelii
}

Igile GO*, Okoi UL, Iwara IA and Eteng MU

Department of Biochemistry, Faculty of Basic Medical Sciences, University of Calabar, PMB 1115, Calabar, Nigeria

*Corresponding author: Igile GO, Department of Biochemistry, Faculty of Basic Medical Sciences, University of Calabar, PMB 1115 , Calabar, Nigeria, Tel: +234 705 689 1371; E-mail: goitech2000@yahoo.com

Received: July 11, 2018; Accepted: September 07, 2018; Published: September 17, 2018

Copyright: $\odot 2018$ Igile GO, et al. This is an open-access article distributed under the terms of the Creative Commons Attribution License, which permits unrestricted use, distribution, and reproduction in any medium, provided the original author and source are credited.

\begin{abstract}
The leaf of Ficus vogelii is commonly used as a green-leafy vegetable in Northern Cross River State of Nigeria. Its ethanol extract is used by adults for well-being, while its aqueous extract is used for weaning children and for treatment of pediatric anemia. In this study, the methanol and n-hexane fractions of the leaves were analyzed for volatile organic composition using GC-MS in order to determine the class of constituents that may be responsible for the amelioration of anemia and sustenance of well-being in adults. GC-MS analysis of n-hexane and methanol fractions revealed the presence of several organic constituents including twenty-one (21) volatile compounds in $n$ hexane fraction and thirty-five (35) compounds in methanol fraction. The dominant compounds in the $n$-hexane fraction included, Hexadecanoic acid (3.14\%), n-Nonadecanoic acid (17.81\%), Phytol (38.45\%), Oleic acid (21.20\%) and E-2-Octadecadecen-1-ol (4.77\%); while the dominant compounds in methanol fraction included, Glycerin $(8.44 \%)$, Dimethyl sulphoxide (7.44\%), 2(R), 3(S)-1,2,3,4-Butane tetrol (6.47\%), 17 $\alpha-O H-17$-Cyano-Preg-4-en-3one $(3.10 \%)$, Ethyl- $\beta$-d-glucopyranoside (7.25\%), Bicyclo [3.1.0] hexan-3-ol (10.11\%); n-Hexadecanoic acid $(15.42 \%)$ and Oleic Acid (21.40\%). It was concluded that the presence of Palmitaldehyde diisopentyl acetate $(2.52 \%)$ in the $n$-hexane fraction may contribute significantly to the pleasant flavor of the extract fraction and its nutritional acceptability. It was also concluded that the high content of oleic acid and phytol in the plant may be responsible for the cardiovascular benefits the plant confers on the populations consuming it, as both compounds are known to lower blood cholesterol lipids in adult humans.
\end{abstract}

Keywords: Ficus vogelii; Methanol fraction; n-hexane fraction; Volatile organic compounds; GC-MS

\section{Introduction}

Ficus vogelii is a small tree of about $10-20 \mathrm{~m}$ tall which grows in most tropical climates [1]. It belongs to the family of Moraceae. The tree is widely distributed in Africa. It is found in all of West African countries including Nigeria, Ghana, Senegal and Mali; and grows in the Congo on to some East African countries including, Uganda, Cameroun and Tanzania [2].

Ficus vogelii is commonly called West African Rubber Tree [1]. The leaves of Ficus vogelii are alternate and spirally arranged. They are bluish-green with pale green veins. Its fruits are sessile and yellow when ripe with a fuzzy surface [3]. Ficus vogelii produces fruits which resemble inverted flower [4].

The leaves of Ficus vogelii and Ficus asperifolia look alike externally, except for slight differences in their venation. They co-occur in most tropical and sub-tropical regions of the world. Ficus vogelii is called kujung by the Obudu people of Northern Cross River State. Its leaves are used for the treatment of diarrhea, dysentery and anemia in traditional medicine. The latex of members of the Ficus genus has been reported to give protection from physical assault by pests [5]. Ficus vogelii leaf is used by the Obudu and Bekwarra people of Cross River State as a green leafy vegetable, and as a medicinal herb in ameliorating anemia and diabetic conditions, as well as other endocrine complications.

The leaves are prepared as vegetables in soups and used traditionally in the treatment of anemia, and for well-being in adults. This is because adults believe that eating various dishes prepared with the leaves guarantees them good health and well-being. This study discovered that traditionally, there are claims that the bark and root are used in treating urinary tract infection, asthma, diabetes and malaria. This claim was supported by literature in which the bark was reported to have been used in treating urinary infection, cardiovascular diseases, and kidney diseases and cough [6].

It was on account of these claims, that we started research work on the chemical and photochemical constituents of this plant in order to relate the medicinal activities of the plant to its natural and bioactive constituents.

\section{Materials and Methods}

\section{Collection of plant material}

Fresh mature Ficus vogelii leaves were harvested from a farm in Obudu Local Government Area of Cross River State of Nigeria. The plant was then authenticated by a botanist in the Botany Department of the University of Calabar, Nigeria. Rat chow feed was purchased from Grand Cereals Limited in Aba, Abia State of Nigeria.

\section{Sample preparation for GC-MS Analysis for volatile organic compounds}

One $\mathrm{kg}$ of the leaves was washed, cut into small pieces and air-dried at room temperature $\left(27 \pm 1.50^{\circ} \mathrm{C}\right)$ for seven days. The leaves were then blended using a manual blender into coarse powder and stored in air tight plastic containers until use. $500 \mathrm{~g}$ of the coarse powder was macerated with $2000 \mathrm{ml}$ of $80 \%$ ethanol in a ratio of $1: 4$ for two days. 
Page 2 of 6

This allowed the sample to have sufficient contact with the solvent to increase its extraction efficiency of bioactive volatile compounds. The extract was then filtered using a cheese cloth and concentrated in vacuo using a rotary evaporator to remove all alcohol and afford $55 \mathrm{~g}$ of the crude extract which was stored under refrigeration.

\section{Fractionation of extract by column chromatography}

Glass column chromatography was packed with silica gel (Silane 343, pore size $0.15 \mu \mathrm{m}$ ) for reverse phase fractionation of the crude extract. The packed column was washed with $30 \%$ methanol and stabilized by washing with distil water. $5 \mathrm{~g}$ of the crude extract was applied to the column and allowed to stand for 5 minutes. The column was then eluted with $n$-hexane, followed by $30 \%$ methanol to afford nhexane and 30\% methanol fractions respectively. All fractions obtained were concentrated in vacuo to afford alcohol-free extracts which were later diluted 1:20 in their respective solvents for GC-MS analysis.

\section{GC-MS analysis of methanol fraction}

Diluted samples (1/20 in $n$-hexane and $1 / 20$ in methanol) were injected manually through the injector port. An Agilent 6890 GC coupled with a 5973i mass spectrometer (Agilent Technologies, Palo Alto, CA, USA) was used. The GC was equipped with a HP-5MS capillary column $(30 \mathrm{~m} \times 250 \mu \mathrm{m}$ i.d. $\times 0.25 \mu \mathrm{m}$, Agilent Technologies). Helium was the carrier gas with a constant flow of 1 $\mathrm{mL} / \mathrm{min}$ to the column. The initial oven temperature was at $40^{\circ} \mathrm{C}$, holding for $2 \mathrm{~min}$, then raised to $150^{\circ} \mathrm{C}$ at $5^{\circ} \mathrm{C} / \mathrm{min}$; and finally raised to $280^{\circ} \mathrm{C}$ at $15^{\circ} \mathrm{C} / \mathrm{min}$, holding for $2 \mathrm{~min}$. The injection port was maintained at splitless mode. The mass detector was operated at $150^{\circ} \mathrm{C}$ in electron impact (EI) mode at $70 \mathrm{eV}$. The ion source temperature was at $230^{\circ} \mathrm{C}$ and the transfer line temperature was maintained at $250^{\circ} \mathrm{C}$. The chromatograms were recorded by monitoring the total ion currents in the 15-450 mass range. MS was detected with 2 min solvent delay. Analysis of the sample at each condition was repeated twice to ensure consistency. C6-C24 n-alkanes were ran under the same chromatographic conditions in order to calculate the retention indices (RI) of detected compounds. Identification of the oil and volatile constituents was based on retention indices relative to n-alkanes (C8C24), and computer matching with the WILLEY 275.L library, and those contained in the NIST08 database; and confirmed by comparison of the retention times (RIs), as well as by comparison of their mass spectral fragmentation patterns with those reported in literature.

Compounds were identified by comparing their mass spectra with those contained in the NIST08 database, and confirmed by comparison of the retention times of the separated constituents with those of the authentic samples and by comparison of retention indexes (RIs) of the separated constituents with the RIs reported in the literature

\section{Results}

Twenty-one (21) compounds were identified in the $n$-hexane fraction (Figure 1, Table 1), while thirty-five (35) compounds were identified in the methanol fraction (Figure 2, Table 2). The dominant compounds in the n-hexane fraction included, Hexadecanoic acid (3.14\%), n-Nonadecanoic acid (17.81\%), Phytol (38.05\%), Oleic acid (21.20\%) and E-2-Octadecadecen-1-ol (4.77\%); while the dominant compounds in the methanol fraction included, Glycerin $(8.44 \%)$, Dimethyl sulphoxide (7.44\%), 2(R), 3(S)-1,2,3,4-Butane tetrol (6.47\%), $17 \alpha-\mathrm{OH}-17 \beta$-Cyano-Preg-4-en-3-one(3.10\%),

Ethyl- $\beta$ - $d-$ glucopyranoside(7.25\%), Bicyclo[3.1.0]hexan-3-ol (10.11\%); nHexadecanoic acid (15.42\%) and Oleic Acid (21.40\%). Several organic acids partitioned into the $\mathrm{n}$-hexane solvent fraction and these included C9-C24 compounds. The C9 compound was shown to be n-Nonanoic Acid (Mol. Wt. $\mathrm{C}_{9} \mathrm{H}_{18} \mathrm{O}_{2}$ ) and per cent abundance of $1.19 \%$. The $\mathrm{C} 24$ organic acid was identified to be oleic acid (Mol. wt. $\mathrm{C}_{18} \mathrm{H}_{34} \mathrm{O}_{2}$ ), and $21.20 \%$ abundance in the plant. Several sugars were extracted by the methanol fraction and these included, D-Erythro-2-deoxy-pentose sugar (2.11\%), 1-Deoxy-d-Arabitol (0.56\%), Ethyl- $\alpha$-dglucopyranoside (7.25\%), Methyl- $\alpha$-d-galactopyranoside (1.01\%), Methyl- $\beta$-d-galactopyranoside (1.20\%), Ethyl- $\beta$-d-Riboside $(0.32 \%)$, and 1,6-Anhydro- $\beta$-D-glucopyranoside $(0.12 \%)$.

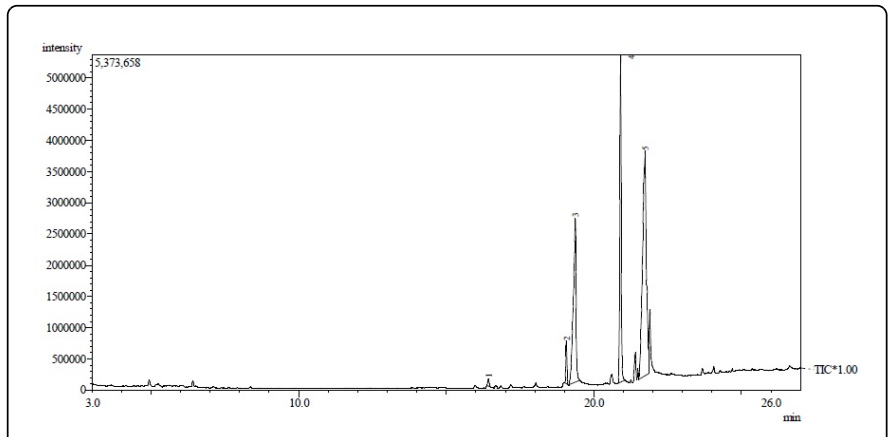

Figure 1: GC-MS Chromatogram of n-Hexane fraction of Ficus vogelii.

\begin{tabular}{|l|l|l|l|l|l|}
\hline Peak Number & Ret Time (Min) & Name of Compound & Mol. Form & Mol. wt. & \% Abundance \\
\hline 1 & 16.47 & n-Tetradecen-1-ol acetate & $\mathrm{C}_{16} \mathrm{H}_{10} \mathrm{O}_{2}$ & 254 & 0.32 \\
\hline 2 & 16.82 & 1-Nonyne & $\mathrm{C}_{9} \mathrm{H}_{16}$ & 124 & 0.22 \\
\hline 3 & 16.93 & 1 -2-Epoxytetradecane & $\mathrm{C}_{14} \mathrm{H}_{28} \mathrm{O}$ & 212 & 0.17 \\
\hline 4 & 17.44 & 2-Decan-1-ol & $\mathrm{C}_{10} \mathrm{H}_{20} \mathrm{O}$ & 156 & 0.19 \\
\hline 5 & 17.81 & 1-Dodecyne & $\mathrm{C}_{12} \mathrm{H}_{22}$ & 166 & 0.06 \\
\hline 6 & 19.07 & Hexadecanoic Acid & $\mathrm{C}_{18} \mathrm{H}_{36} \mathrm{O}_{2}$ & 284 & 3.14 \\
\hline 7 & 19.08 & Pentadecanoic Acid & $\mathrm{C}_{20} \mathrm{H}_{40} \mathrm{O}$ & 312 & 0.45 \\
\hline
\end{tabular}


Citation: Igile GO, Okoi UL, Iwara IA, Eteng MU (2018) Volatile Organic Constituents of Two Fractions of Leaves of Ficus vogelii. Nat Prod Chem Res 6: 344. doi:10.4172/2329-6836.1000344

Page 3 of 6

\begin{tabular}{|l|l|l|l|l|l|}
\hline 8 & 19.11 & Docosanoic Acid & $\mathrm{C}_{24} \mathrm{H}_{48} \mathrm{O}_{2}$ & 368 & 0.32 \\
\hline 9 & 19.14 & Octadecanoic Acid & $\mathrm{C}_{20} \mathrm{H}_{40} \mathrm{O}_{2}$ & 312 & 0.59 \\
\hline 10 & 19.25 & Tridecanoic Acid & $\mathrm{C}_{15} \mathrm{H}_{30} \mathrm{O}_{2}$ & 242 & 0.40 \\
\hline 11 & 19.37 & n-Nonadecanoic Acid & $\mathrm{C}_{19} \mathrm{H}_{38} \mathrm{O}_{2}$ & 298 & 17.81 \\
\hline 12 & 19.45 & n-Decanoic Acid & $\mathrm{C}_{10} \mathrm{H}_{20} \mathrm{O}_{2}$ & 172 & 2.22 \\
\hline 13 & 19.71 & n-Nonanoic Acid & $\mathrm{C}_{9} \mathrm{H}_{18} \mathrm{O}_{2}$ & 158 & 1.19 \\
\hline 14 & 20.91 & Hexadecan-1-ol (Phytol) & $\mathrm{C}_{20} \mathrm{H}_{40} \mathrm{O}$ & 296 & 38.05 \\
\hline 15 & 20.95 & Palmitaldehyde diisopentyl acetate & $\mathrm{C}_{26} \mathrm{H}_{54} \mathrm{O}_{2}$ & 398 & 2.52 \\
\hline 16 & 20.98 & 2,6 -dimethyl-1,7-Octadien-3-ol & $\mathrm{C}_{10} \mathrm{H}_{18} \mathrm{O}$ & 154 & 2.15 \\
\hline 17 & 21.73 & Oleic Acid & $\mathrm{C}_{18} \mathrm{H}_{34} \mathrm{O}_{2}$ & 282 & 21.20 \\
\hline 18 & 21.77 & E-2-Octadecadecen-1-ol & $\mathrm{C}_{18} \mathrm{H}_{36} \mathrm{O}$ & 268 & 4.77 \\
\hline 19 & 21.84 & (9E)-9-Octadecenal & $\mathrm{C}_{18} \mathrm{H}_{34} \mathrm{O}$ & 266 & 2.19 \\
\hline 20 & 21.91 & Z-10-Pentadecen-1-ol & $\mathrm{C}_{15} \mathrm{H}_{30} \mathrm{O}$ & 226 & 0.55 \\
\hline 21 & 21.97 & E-9-Tetradecenoic Acid & $\mathrm{C}_{14} \mathrm{H}_{26} \mathrm{O}$ & 226 & 0.21 \\
\hline
\end{tabular}

Table 1: Volatile Organic Constituents of n-Hexane fraction of Ficus vogelii using GC-MS Analysis.

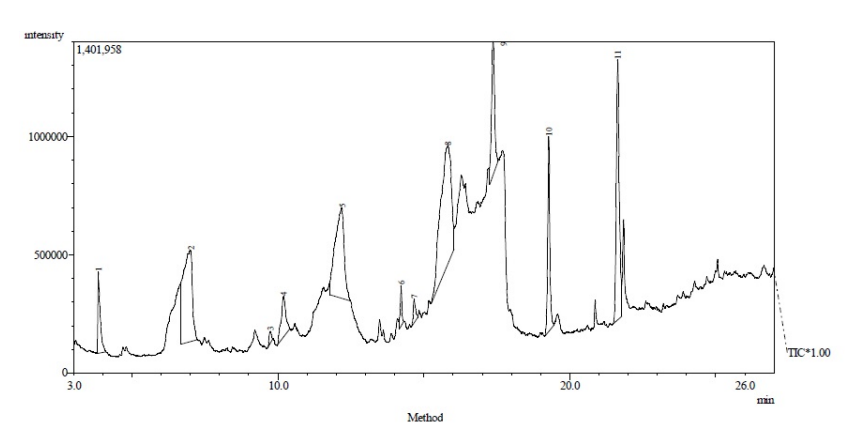

Figure 2: GC-MS Chromatogram of Methanol fraction of Ficus vogeli.

\begin{tabular}{|l|l|l|l|l|l|}
\hline Peak Number & Ret Time (Min) & Name of Compound & Mol. Form & Mol. wt. & \% Abundance \\
\hline 1 & 3.84 & Dimethyl Sulphoxide & C2H6OS & 78 & 7.44 \\
\hline 2 & 7.01 & $1,2,3-$-Propanetriol (Glycerin) & C3H8O3 & 92 & 8.44 \\
\hline 3 & 9.73 & Phenoxyethylene & $\mathrm{C}_{8} \mathrm{H}_{8} \mathrm{O}$ & 120 & 0.85 \\
\hline 4 & 9.94 & $\begin{array}{l}\text { 6-Methylene-bicyclo [3.2.0] Hept-3- } \\
\text { en-2-one }\end{array}$ & $\mathrm{C}_{8} \mathrm{H}_{8} \mathrm{O}$ & 120 & 0.25 \\
\hline 5 & D-Erythro-2-deoxy-pentose sugar & $\mathrm{C}_{5} \mathrm{H}_{10} \mathrm{O}_{4}$ & 134 & 2.11 \\
\hline 6 & 10.19 & 1-Deoxy-d-Arabitol & $\mathrm{C}_{5} \mathrm{H}_{12} \mathrm{O}_{4}$ & 136 & 0.56 \\
\hline 7 & 10.72 & $1,2,3-$-Butanetriol & $\mathrm{C}_{4} \mathrm{H}_{10} \mathrm{O}_{3}$ & 106 & 0.29 \\
\hline
\end{tabular}


Citation: Igile GO, Okoi UL, Iwara IA, Eteng MU (2018) Volatile Organic Constituents of Two Fractions of Leaves of Ficus vogelii. Nat Prod Chem

\begin{tabular}{|c|c|c|c|c|c|}
\hline 8 & 11.01 & 2-Isopropoxyethylamine & $\mathrm{C}_{5} \mathrm{H}_{13} \mathrm{NO}$ & 103 & 0.80 \\
\hline 9 & 12.18 & 2(R),3(S)-1,2,3,4-Butane tetrol & $\mathrm{C}_{4} \mathrm{H}_{10} \mathrm{O}_{4}$ & 122 & 6.49 \\
\hline 10 & 12.66 & 3,4-Furandiol & $\mathrm{C}_{4} \mathrm{H}_{8} \mathrm{O}_{3}$ & 104 & 1.27 \\
\hline 11 & 14.22 & $\begin{array}{l}\text { 3,4-Dimethyl } \\
\text { Dihydrothiophene 1,1-dioxide }\end{array}$ & $\mathrm{C}_{9} \mathrm{H}_{14} \mathrm{O}_{2} \mathrm{~S}$ & 186 & 0.55 \\
\hline 12 & 14.26 & 17a-OH-17ß-Cyano-Preg-4-en-3-one & $\mathrm{C}_{20} \mathrm{H}_{27} \mathrm{NO}_{2}$ & 313 & 3.10 \\
\hline 13 & 14.32 & $Z, Z, Z-1,4,6,9$ - Nonadecatetraene & $\mathrm{C}_{19} \mathrm{H}_{32}$ & 260 & 0.21 \\
\hline 14 & 14.44 & $\begin{array}{l}\text { 3-Bromo-7-methyl-1-adamantane } \\
\text { Carboxylic acid }\end{array}$ & $\mathrm{C}_{12} \mathrm{H}_{17} \mathrm{BrO}_{2}$ & 272 & 0.11 \\
\hline 15 & 14.59 & $5,8,10$-Undecatrien-3-ol & $\mathrm{C}_{11} \mathrm{H}_{18} \mathrm{O}$ & 166 & 0.31 \\
\hline 16 & 14.67 & $\begin{array}{l}\text { 3-Methyl-4-(phenylthio)-2-prop-2- } \\
\text { enyl-2,5-dihydrothiophene,1,1 Dioxide }\end{array}$ & $\mathrm{C}_{14} \mathrm{H}_{16} \mathrm{O}_{2} \mathrm{~S}_{2}$ & 280 & 1.77 \\
\hline 17 & 14.71 & 3-Octyn-2-ol & $\mathrm{C}_{8} \mathrm{H}_{14} \mathrm{O}$ & 126 & 0.21 \\
\hline 18 & 14.79 & $\begin{array}{l}\text { 5-Isopropenyl-1,2-dimethyl-cyclo- } \\
\text { Hex-2-enol }\end{array}$ & $\mathrm{C} 11 \mathrm{H} 18 \mathrm{O}$ & 166 & 0.20 \\
\hline 19 & 14.84 & $\begin{array}{l}\text { Acetic acid, 7-oxo-bicyclo [3.2.1] } \\
\text { Hept-2-yl ester }\end{array}$ & $\mathrm{C} 9 \mathrm{H} 12 \mathrm{O} 3$ & 168 & 0.03 \\
\hline 20 & 14.97 & Trans-Z- $\alpha$-Bisabolene epoxide & $\mathrm{C} 15 \mathrm{H} 24 \mathrm{O}$ & 220 & 0.07 \\
\hline 21 & 15.81 & Ethyl-a-d-glucopyranoside & $\mathrm{C} 8 \mathrm{H} 16 \mathrm{O} 6$ & 208 & 7.25 \\
\hline 22 & 15.94 & Methyl- $\beta$-d-galactopyranoside & $\mathrm{C} 7 \mathrm{H} 14 \mathrm{O} 6$ & 194 & 1.20 \\
\hline 23 & 15.97 & Methyl-a-d-galactopyranoside & $\mathrm{C} 7 \mathrm{H} 14 \mathrm{O} 6$ & 194 & 1.01 \\
\hline 24 & 15.99 & Ethyl- $\beta$-d-Riboside & $\mathrm{C} 7 \mathrm{H} 14 \mathrm{O} 5$ & 178 & 0.32 \\
\hline 25 & 16.03 & 1,6-Anhydro- $\beta$-D-glucopyranoside & $\mathrm{C} 6 \mathrm{H} 10 \mathrm{O} 5$ & 162 & 0.12 \\
\hline 26 & 17.36 & Bicyclo[3.2.0]-hexan-3-ol & $\mathrm{C} 10 \mathrm{H} 18 \mathrm{O}$ & 154 & 10.11 \\
\hline 27 & 17.45 & (E)-9-Tetradecen-1-ol, acetate & $\mathrm{C} 16 \mathrm{H} 30 \mathrm{O} 2$ & 254 & 1.02 \\
\hline 28 & 17.62 & 3,5-Octadienoic acid & $\mathrm{C} 9 \mathrm{H} 14 \mathrm{O} 3$ & 170 & 0.11 \\
\hline 29 & 17.88 & a-Limonene diepoxide & $\mathrm{C} 10 \mathrm{H} 16 \mathrm{O} 2$ & 168 & 1.01 \\
\hline 30 & 19.28 & n-Hexadecanoic acid & $\mathrm{C} 16 \mathrm{H} 32 \mathrm{O} 2$ & 256 & 15.42 \\
\hline 31 & 19.44 & n-Nonadecanoic acid & $\mathrm{C} 19 \mathrm{H} 38 \mathrm{O} 2$ & 298 & 1.20 \\
\hline 32 & 19.67 & n-Decanoic acid & $\mathrm{C} 10 \mathrm{H} 20 \mathrm{O} 2$ & 172 & 0.22 \\
\hline 33 & 19.89 & n-Capric acid & $\mathrm{C} 13 \mathrm{H} 26 \mathrm{O} 2$ & 214 & 1.10 \\
\hline 34 & 21.64 & Oleic acid & $\mathrm{C} 18 \mathrm{H} 34 \mathrm{O} 2$ & 282 & 21.40 \\
\hline 35 & 21.98 & E-11-Tetradececenoic acid & $\mathrm{C} 14 \mathrm{H} 26 \mathrm{O} 2$ & 226 & 2.55 \\
\hline & & & & Total & 100.00 \\
\hline
\end{tabular}

Table 2: Organic Constituents of Methanol fraction of Ficus vogelii using GC-MS.

\section{Discussion}

GC-MS analysis of $n$-hexane and methanol fractions revealed the presence of fifty-six (56) bioactive organic constituents including, twenty-one (21) volatile compounds in the n-hexane fraction and thirty-five (35) compounds in the methanol fraction. The dominant compounds in the n-hexane fraction included, Hexadecanoic acid
(3.14\%), n-Nonadecanoic acid (17.81\%), Phytol (38.45\%), Oleic acid (21.20\%) and E-2-Octadecadecen-1-ol (4.77\%). On the other hand, the dominant compounds in the methanol fraction included, Glycerin (8.44\%), Dimethyl sulphoxide (7.44\%), $2^{\circ}, 3(\mathrm{~S})-1,2,3,4$-Butane tetrol (6.47\%), 17a-OH-17 $\beta$-Cyano-Preg-4-en-3-one (3.10\%), Ethyl- $\beta$-dglucopyranoside (7.25\%), Bicyclo[3.1.0]hexan-3-ol (10.11\%); n- 
Page 5 of 6

Hexadecanoic acid (15.42\%) and Oleic Acid (21.40\%). Others include, D-Erythro-pentose sugar; tetrahydro-3,4-furandiol; 5,8,10Undecatrien-3-ol; 3-Octyn-2-ol; and levo-glucosan.

The presence of Palmitaldehyde diisopentyl acetate (2.5\%) in the $\mathrm{n}$ hexane fraction, suggests the biogenetic origin of most of the volatile organic compounds detected in the plant. Also, Palmitaldehyde diisopentyl acetate may be the major contributing aldehydic ester to the pleasant flavor of the extracts of this plant and its nutritional acceptability by the consumers.

Oleic acid is a fatty acid that occurs naturally in various animal and vegetable fats and oils, and is classified as a monounsaturated Omega-9 fatty acid. Oleic acid has been reported to reduce high blood pressure, increase fat burning to help with weight loss, protect cells from free radical damage, and may prevent type 2 diabetes [7]. It is also said to prevent ulcerative colitis and generates brain myelin [8]. As an Omega-9 fatty acid, it contributes to reduction of HDL-cholesterol and confers protection to the heart [9].

n-Nonadecanoic acid, is a 19-carbon long chain saturated fatty acid with the chemical formula $\mathrm{CH}_{3}\left(\mathrm{CH}_{2}\right)_{17} \mathrm{COOH}$. It is found widely distributed in animal fats and vegetable oils. It is also used by insects as pheromones [10].

$17 \alpha-\mathrm{OH}-17 \beta$-Cyano-Preg-4-en-3-one is a chemical intermediate in the biosynthesis of many other endogenous steroids, including androgens, estrogens, glucocorticoids, and mineralocorticoids, as well as neuro-steroids $[11,12]$. It is the precursor to $17 \alpha-\mathrm{OH}$-progesterone (17a-OHP) which is an agonist of the progesterone receptor (PR) similarly to progesterone [13,14]. 17a-OHP increases in the third trimester of pregnancy primarily due to fetal adrenal production [15].

Phytol is the product of chlorophyll metabolism in plants. It is chemically called an acrylic diterpene alcohol which is used in the manufacture of Vitamin E and K. Both of these vitamins are known to play very important functions in the human body. The use of phytol in the human body is indispensable. It is essential in activating enzymes that have a positive effect in the production of insulin. It was also reported to be effective in decreasing blood cholesterol levels [16].

Hexadecanoic acid (Palmitic acid) is a saturated fatty acid and the main acid in Red Palm Oil (RPO). It is commonly found in both animals and plants. Many medical authorities, such as the World Health Organization, say dietary intake of saturated fats such as palm oil (palmitic acid) increases the risk of cardiovascular diseases [16]. However, in moderation, palmitic acid might not be entirely bad for you, as it does display mild antioxidant and anti-atherosclerotic properties, at least in animal studies. In general, diets higher in unsaturated fats are considered healthier [16].

Several sugars were extracted by the methanol fraction and these included, D-Erythro-2-deoxy-pentose sugar (2.11\%), 1-Deoxy-dArabitol (0.56\%), Ethyl- $\alpha$-d-glucopyranoside (7.25\%), Methyl- $\alpha$-dgalactopyranoside (1.01\%), Methyl- $\beta$-d-galactopyranoside $(1.20 \%)$, Ethyl- $\beta$-d-Riboside (0.32\%), and 1,6-Anhydro- $\beta$-D-glucopyranoside $(0.12 \%)$. These sugars are glucose precursors and its isomers, which may provide energy to children recovering from anemic conditions and its complications such as PEM. The sugars may contribute to the overall well-being reported by adults consuming the extracts.

D-Erythro-2-deoxy-pentose sugar is a Deoxy-ribose sugar. The term "2-deoxyribose" may refer to either of two enantiomers: the biologically important D-2-deoxyribose and to the rarely encountered mirror image L-2-deoxyribose [17]. D-2-deoxyribose is a precursor to the nucleic acid DNA. 2-deoxyribose is an aldopentose, which is a monosaccharide with five carbon atoms and having an aldehyde functional group [17].

\section{Conclusion}

The study revealed the volatile organic constituents in the leaves of Ficus vogelii. It was concluded that the high content of oleic acid and phytol in the plant may be responsible for the cardiovascular benefits the plant confers on the populations consuming it.

\section{Acknowledgement}

We thank Fedorosa Catolini for the financial support given to the first author to carry out this study.

\section{References}

1. Arbonnier M (2004) Trees, shrubs and lianas of West African Dry Zones. Quae.

2. Neuwinger HD (2000) African traditional Medicine; a dictionary of plant use and applications. Medpharm Scientific, Stuggart, p: 589.

3. United States Department of Agriculture (USDA) (2014) Macronutrients: importance of carbohydrate, protein and fat.

4. Sirisha N, Sreenivasulu M, Sangeeta K, Madhusudhana Chetty C (2010) Antioxidant Properties of Ficus Species-A Review. International Journal of Pharmtech Research 24: 2174-2182.

5. Ephraim P, Pavilalinen H, Pawlus A, Newman R (2008) Ficus Spp: Ethnopharmacology, and Potential as anticancer and anti-inflammatory agents. Journal of Ethnobotany 119: 195-213.

6. Fern K (2014) Useful Tropical Plants Database. Recuperado.

7. Ochoa JJ, Pamplona R, Ramirez-Tortosa MC, Granados Principal S, Perez-Lopez P, et al. (2011) Age-related changes in brain mitochondrial DNA deletion and oxidative stress are differentially modulated by dietary fat type and coenzyme Q1. Free Radic Biol Med 50: 1053-1064.

8. Natali F, Siculella L, Salvati S, Gnoni GV (2007) Oleic acid is a potent inhibitor of fatty acid and cholesterol synthesis in C6 glioma cells. J Lipid Res 48: 1966-1975.

9. Lahey R, Wang X, Carley AN, Lewandowski ED (2014) Dietary fat supply to failing hearts determines dynamic lipid signaling for nuclear receptor activation and oxidation of stored triglyceride. Circulation 130: 1790-1799.

10. Fukuzawa M, Yamaguchi R, Hide I, Chen Z, Hirai Y, et al. (2008) Possible involvement of long chain fatty acids in the spores of Ganoderma lucidum (Reishi Houshi) to its anti-tumor activity. Biological and Pharmaceutical Bulletin 31: 1933-1937.

11. Elks J (2014) The Dictionary of Drugs: Chemical Data: Chemical Data, Structures and Bibliographies. Springer, pp: 664-665.

12. Kang S, Kaiyu L, Li C, Georgiou Ektoras X, Sooranna Suren R, et al. (2012) Progesterone Acts via the Nuclear Glucocorticoid Receptor to Suppress IL-1 $\beta$-Induced COX-2 Expression in Human Term Myometrial Cells. PloS one 7: e50167.

13. Morton KI, Hall JM (2012) Concise Dictionary of Pharmacological Agents: Properties and Synonyms. Springer Science and Business Media, p: 146 .

14. Pijnenburg Kleizen KJ, Engels M, Mooij CF, Griffin A, Krone N, et al. (2015) Adrenal Steroid Metabolites Accumulating in Congenital Adrenal Hyperplasia led to Transactivation of the Glucocorticoid Receptor. Endocrinology, p: 156.

15. Attardi BJ, Zeleznik A, Simhan H, Chiao JP, Mattison DR, et al. (2007) Comparison of progesterone and glucocorticoid receptor binding and stimulation of gene expression by progesterone, 17-alpha hydroxyprogesterone caproate, and related progestins. Am J Obstet Gynecol 197: 599. 
Citation: Igile GO, Okoi UL, Iwara IA, Eteng MU (2018) Volatile Organic Constituents of Two Fractions of Leaves of Ficus vogelii. Nat Prod Chem Res 6: 344. doi:10.4172/2329-6836.1000344

Page 6 of 6

16. Fattore E, Fanelli R (2013) Palm oil and palmitic acid: a review on cardiovascular effects and carcinogenicity. Int J Food Sci Nutr 64: 648-659.
17. Bernelot Moens C, Demple B (1989) Multiple DNA repair activities for 3'-deoxyribose fragments in Escherichia coli. Nucleic Acids Research 17: 587-600. 